\title{
Cultural Transformation in the Development of Home Industries in Karanganyar Regency, Central Java, Indonesia
}

\author{
Eny Lestari ${ }^{1}$, Agung Wibowo ${ }^{1, *}$ and Paramita Rahayu $^{2}$ \\ ${ }^{1}$ Faculty of Agriculture, Universitas Sebelas Maret, Jl. Ir. Sutami 36 A, Surakarta, Indonesia \\ ${ }^{2}$ Faculty of Engineering, Universitas Sebelas Maret, Jl. Ir. Sutami 36 A, Surakarta, Indonesia
}

\begin{abstract}
The development of home industries based on cultural values is one of the strategies used by the Indonesian government to alleviate poverty in rural communities. In the development of home industries, a model of cultural transformation based on local wisdom offers opportunities for communities to show their local identity and local potential as well as displaying their own uniqueness. The goal of this research is to discover how the transformation of local culture based on local wisdom takes place in the development of home industries in rural communities. The research method is qualitative and uses a case study approach which examines the shift in cultural values and the importance of local wisdom in the development of home industries. In this case study, the data collection includes various sources, such as observation, interviews, FGDs, audio visual material, documents, and reports. The research results show that the development of home industries in rural areas is full of dynamics in the cultural transformation from an agrarian culture to an industrial culture. This cultural transformation has a multiplier effect and acts as a trigger and determining factor in rural development.
\end{abstract}

\section{Introduction}

Industries in Indonesia are regulated in Law No. 3 Year 2014 about Industry. Industry encompasses all forms of economy activity that process raw materials and/or utilize industrial resources to produce goods that have added value or higher benefit, including industrial services [1]. It is hoped that the presence of the industrial revolution 4.0 and society 5.0 will provide a positive value for MSMEs in developing their activities in rural areas that are far from urban centers and untouched by communication technology infrastructure [2]. Nevertheless, in social and cultural aspects there are striking differences between modern industrial communities, which are more modern by nature, and more traditional farming communities. This has unknowingly led to a number of quite fundamental changes in the structure and social values of the family unit and the community [3].

\footnotetext{
* Corresponding author: agungwibowo@staff.uns.ac.id
} 
The introduction of industries into rural areas has proven successful in reducing the current of large-scale urbanization, as well as providing more job openings in rural areas and improving welfare in rural communities [4]. The positive impact of this change is that it has improved the economy of these communities, created jobs, empowered human resources, and led to modernization [5]. Industrialization helps with economic growth and the development of various economic activities such as trade, agriculture, transportation, and entrepreneurship, thus supporting the growth and development of the national economy [6], [7], but since the 1990s, the social stratification that has taken place has focused on social and cultural factors as the cause of inequality [8].

The industrialization of village communities and the development of strategic processing industries aim to strengthen ethnicity and facilitate village development. The rapid development of industries in rural areas is aided by adequate technology. The development of small industries usually has the ability to grow core industries, which in turn leads to better growth of technology innovation-based industries, an increase in the competence of human resources, the emergence of new entrepreneurs, the absorption of local workforces, and an improvement in village economy, through the balance of added value for related business practitioners and cooperatives, leading to the development of villages or independent industrial centers that are environmentally friendly. However, the expansion of industrial activities in farming communities has the strong potential to influence or change the social and cultural conditions of the community concerned, as well as potentially presenting an unfavorable experience for members of the farming community in their interaction with outside parties [9].

The atmosphere in rural areas is experiencing an important transformation, with a number of service sectors (such as the travel industry, tourism industry, and food industry) taking on a key role in the rural economy, and for this reason it is necessary to implement innovative strategies in order to compete in the global market, and build sustainable tourism [10], [11]. Developments in ecotourism are taking place at the same time as the industrial revolution 4.0, leading to fundamental changes in human lifestyles and work processes, where advances in information technology can become integrated in a digital world that has an impact on various disciplines. The appearance of the industrial revolution 4.0 has had far-reaching effects on almost all areas of human life, and the ecotourism industry is no exception. Therefore, ecotourism activities in Indonesia, which are in need of careful management, must be re-analyzed with the various new challenges that have already been explained, in order to realize sustainable tourism development [12].

It is feared that the significant changes that have taken place in such a short space of time will undermine the existence of farmers' social capital [13]. In areas where industrialization is not sufficiently intensive, local communities will be encouraged to migrate to other areas in order to seek broader job opportunities, thus altering their local values [14]. The presence of industries is gradually altering and eroding social structures, and as a result, life patterns within communities are becoming increasingly complex. This is evident in a social life that is characterized on a daily basis by high work intensity, a lifestyle that is caused by the existence of a high proportion of work. The limited shared time available, due to people working different shifts, does not allow them to participate in activities in their villages. As a consequence, family values such as gotong royong (mutual cooperation) and siskamling (community security program) are tending to disappear [15].

It will not be possible for production to increase on an ongoing basis if the needs of a community remain the same and continue to preserve the essentially anthropological nature that does not depend either on social or historical developments [16]. It is important to understand how this kind of rural development through agrarian industrialization or increased area-based and economic growth-based food production, along with an economic, social, and creative-based approach to rural development has the power to activate the 
village economy. Agriculture, which is part of the primary sector, is beginning to be viewed as less important and pushed aside by industrialization, when in fact agricultural products are urgently needed for food security and industrial input, as well as having the ability to absorb a large workforce, and provide an income [17].

It is an inherent part of human nature that people are born to become social creatures who cannot live alone. As individuals, people tend to enjoy socializing with others and sharing their lives with other people in a particular area that they find compatible. The process of continuous change from diversity to homogeneity cannot be stopped. This is influenced by: (1) stages of time; (2) the ease that makes it possible to pass through space; (3) the adaptive capability of the system. In addition, homogeneity of an urban or rural landscape will also influence the stability and adaptive capability of urban and rural ecosystems [18]. This research describes the propositions and empirical conditions of communities living in the midst of the development of home industries.

From the explanation above, it can be surmised that in line with the development of home industries in rural areas, a cultural transformation is taking place, from an agrarian culture (social culture) to an industrial culture (economic culture). This will affect the form and nature of gotong royong that exists in the community concerned, and the concept of gotong royong itself has even begun to disappear from the culture of certain communities. There is therefore a need for the revitalization of the system of gotong royong in the social cultural life of rural communities in Indonesia [19]. The reason for this is that gotong royong is a form of local wisdom that is an important entity in the community, specifically in the development of home industries in rural areas. The development of home industries based on cultural values is an important strategy for eradicating poverty in rural communities. As middle road approach in this research, a model of cultural transformation is studied for developing local wisdom-based home industries that provide opportunities for communities to show their local identity and local potential, as well as displaying their own uniqueness. The goal of this research is to discover the propositions and empirical conditions of communities alongside the local cultural transformation based on local wisdom that is taking place in the midst of the development of home industries in rural areas.

\section{Research Method}

The research method is qualitative descriptive in order to obtain a picture of the dimensions of interest in the clashes between social culture and economic culture. A phenomenological approach is used to capture the meaning of people's life experiences in relation to a particular phenomenon and to learn more about the structure of consciousness in the experiences of people who are the actors in home industries. Mulyana describes the phenomenological approach as a subjective or interpretative approach [20], which uses one of two perspectives about human behaviour, namely the objective approach or the subjective approach. The objective approach, which is also often referred to as a behaviouristic and structural approach, assumes that human beings are passive, while the subjective approach considers that research with a case study is conducted to examine and interpret the shift in cultural values taking place and the importance of local wisdom in the development of home industries. According to [21], the process of investigating understanding is based on separate methodological traditions that explore a social or human problem. Case study research "consists of a detailed investigation, often with data collected over a period of time, of phenomena, within their context," with the aim being "to provide an analysis of the context and processes which illuminate the theoretical issues being studied" [22]. The method used for interviewing follows the advice of Moustakas, namely that "The phenomenological interview involves an informal, interactive process and utilities 
open-ended comments and questions" [23]. Littlejohn even goes so far as to emphasize that in qualitative research with a phenomenological perspective, "a phenomenologist never hypothesizes, but carefully examines actual lived experience to see what it looks like" [24]. Hence, the choice of research informants is dependent upon the capability of the people being interviewed to articulate their life experiences.

In this case study research, the data were collected from various sources of information, including observation, in depth interviews, FGDs, audio visual material, documents, and reports [25], [26], [27]. The interviews were carried out with village officials, community figures, farmers, women farmers, and actors of home industries, with the involvement of four students in the field. According to [28], [29], the primary data source in qualitative research is the words and actions of informants obtained through interviews, enhanced by additional data such as documents and other data. The data analysis was carried out with reference to [30], by looking for and compiling systematically all the data obtained from interviews, field notes, and other materials, so that it was easy to understand and the findings could be conveyed to other people. The process of analysis used in this research uses a model of interactive analysis, as described by [31], namely data collection, data reduction, data presentation, and drawing a conclusion.

\section{Research Results and Discussion}

Table 1. Propositions and Empirical Conditions of the Social Life of the Community in the Midst of the Development of Home Industries

\begin{tabular}{|c|c|c|}
\hline No. & $\begin{array}{l}\text { Propositions of } \\
\text { Social Life of } \\
\text { the Community }\end{array}$ & Empirical Conditions of Social Life of the Community \\
\hline \multirow[t]{4}{*}{1} & \multirow{4}{*}{$\begin{array}{l}\text { Decrease in } \\
\text { level of social } \\
\text { capital in the } \\
\text { community }\end{array}$} & $\begin{array}{l}\text { Decrease in the level of trust between members of the community } \\
\text { leading to a further decrease in social capital. }\end{array}$ \\
\hline & & $\begin{array}{l}\text { Decrease in the intensity of mutual cooperation in all aspects of life } \\
\text { (time concentrated more on productive activities related to home } \\
\text { industries leads to a further decline in the intensity of mutual } \\
\text { cooperation). }\end{array}$ \\
\hline & & $\begin{array}{l}\text { Decrease in the intensity of exchanging kindness and good deeds } \\
\text { between members of the community as a result of more calculated } \\
\text { profit and loss in managing home industries. }\end{array}$ \\
\hline & & $\begin{array}{l}\text { Decrease in the intensity of togetherness of community members in } \\
\text { various aspects of life (more difficult to coordinate free time to visit } \\
\text { neighbours who are ill because of home industry activities). }\end{array}$ \\
\hline \multirow[t]{2}{*}{2} & \multirow{2}{*}{$\begin{array}{l}\text { Increase in } \\
\text { transactional } \\
\text { relationships in } \\
\text { the local } \\
\text { community }\end{array}$} & $\begin{array}{l}\text { Mutual aid and assistance in the local community is motivated more by } \\
\text { monetary reward }\end{array}$ \\
\hline & & $\begin{array}{l}\text { People give more priority to work that makes money rather than } \\
\text { working in community service activities for common interests, } \\
\text { preferring to pay a fine rather than participate. }\end{array}$ \\
\hline \multirow[t]{3}{*}{3} & \multirow{3}{*}{$\begin{array}{l}\text { Decrease in } \\
\text { community } \\
\text { participation in } \\
\text { development } \\
\text { activities }\end{array}$} & $\begin{array}{l}\text { Members of the community will participate in stages of development if } \\
\text { they receive payment that makes it worthwhile leaving their own work } \\
\text { in the home industry }\end{array}$ \\
\hline & & $\begin{array}{l}\text { Members of the community will participate in development if it is } \\
\text { relevant to their needs in the development of home industries. }\end{array}$ \\
\hline & & $\begin{array}{l}\text { Members of the community consider matters of development to be the } \\
\text { responsibility of the government so if they are involved it is only right } \\
\text { that they receive payment for their work. }\end{array}$ \\
\hline
\end{tabular}

The research results show that the development of home industries in rural areas is full of dynamics in the cultural transformation from an agrarian culture (social culture) to an 
industrial culture (economic culture). There are numerous social cultures that are closely tied to rural communities, many of which have become integrated with other cultures. These include: 1) Close kinship relationships, 2) Strong social solidarity, 3) Intensive interaction and communication in the community, 4) Social control in rural communities carried out through prevailing norms and values, 5) Mutual cooperation (gotong royong), working together to keep the village clean and secure, 6) Reciprocity (exchanging kindness and good deeds), and 7) Leading a simple lifestyle and dressing modestly. Table 1 shows the propositions and empirical conditions of the social life of the community in the midst of the development of home industries.

Going forward, the involvement of rural communities in the formulation of projects, planning, and implementation must continue to be encouraged alongside the development of home industries. The government must create a conducive environment where grass roots communities will actively participate in the process of making decisions that affect their life conditions, which will stimulate a relationship where the government and rural communities are partners [32]. The phenomena of industrialization and farmers' social capital occurring in local communities are in fact an indication of conformity to the theory abstracted by [33], namely that the influence of industrialization on community social capital generally depends on the characteristics of the community concerned.

Table 2. Propositions and Empirical Conditions of the Economic Life of the Community in the Midst of the Development of Home Industries

\begin{tabular}{|c|c|c|}
\hline No & $\begin{array}{l}\text { Propositions of Economic } \\
\text { Life of the Community }\end{array}$ & Empirical Conditions of Economic Life of the Community \\
\hline \multirow[t]{4}{*}{1} & \multirow[t]{4}{*}{$\begin{array}{l}\text { Development of home } \\
\text { industries leads to } \\
\text { diversification of jobs }\end{array}$} & $\begin{array}{l}\text { Members of the community in the productive age group with } \\
\text { middle level education stay in the local area (do not participate } \\
\text { in urbanization). }\end{array}$ \\
\hline & & $\begin{array}{l}\text { Increase in the number of people who go on to higher } \\
\text { education (university level) in other areas, and seek } \\
\text { employment in cities, outside of the agricultural sector, in } \\
\text { accordance with their qualifications and competency. }\end{array}$ \\
\hline & & $\begin{array}{l}\text { Development of businesses (eating places, grocery shops, } \\
\text { vehicle repair shops etc) that can accommodate the local } \\
\text { workforce }\end{array}$ \\
\hline & & People aged 50 and over continue working as farmers. \\
\hline \multirow[t]{2}{*}{2} & \multirow{2}{*}{$\begin{array}{l}\text { Development of home } \\
\text { industries increases the } \\
\text { development of local } \\
\text { economy }\end{array}$} & $\begin{array}{l}\text { Income level of MSME actors increases alongside an increase } \\
\text { in purchasing power of the local community. }\end{array}$ \\
\hline & & $\begin{array}{l}\text { Increase in the level of daily wages of farmers, labourers and } \\
\text { other workers. }\end{array}$ \\
\hline \multirow[t]{3}{*}{3} & \multirow{3}{*}{$\begin{array}{l}\text { Development of home } \\
\text { industries increases } \\
\text { standards of fulfilling life } \\
\text { necessities }\end{array}$} & $\begin{array}{l}\text { Increase in income level has an impact on the community's } \\
\text { consumption rate in fulfilling their life necessities. }\end{array}$ \\
\hline & & $\begin{array}{l}\text { Increase in cosmopolitan level of the local community in terms } \\
\text { of frequency and radius of travel outside their own area. }\end{array}$ \\
\hline & & $\begin{array}{l}\text { Increase in number and intensity of people visiting tourist } \\
\text { objects. }\end{array}$ \\
\hline
\end{tabular}

In their adaptation to a cultural economy, local communities still continue to perform rituals as a way of adapting to the environment. On one hand, the performing of these rituals does build solidarity and togetherness, but on the other hand it also fails to encourage the confidence of individuals to make change, let alone develop a spirit of business. When there is a habit of doing something together that is supported by mutual help, it feels strange for people to act alone when doing business. The economic potential of the present time becomes an important target for an an area to build and revive community participation [34]. Table 2 presents the propositions and empirical 
conditions of the economic life of the community in the midst of the development of home industries.

There are, however, a number of unwritten values of local wisdom that continue to be adhered to today by local communities, thus ensuring that common interests still take main priority in the social life of the community. The consequence of this is that when members of a community fail to abide by conventions (unwritten rules or agreements), they will receive social sanctions (be ostracized by the community). The following statement was made by one local resident: "bakulan lan sakjenise iku ndadekake wong ora lumrah karo tonggo teparuh, sing di udi mung dhuit karo bondho, mangkane ndadekake wong medhit, etungan lan ora peduli tonggo teparuh", which means that doing trade and other similar activities makes people stop caring about their neighbours, all they care bout is making money, and this makes people stingy, too calculating, and unresponsive to their neighbours. This statement by Mbah Sadiyem (a resident of Menjing Village) is proof that local wisdom plays an important role in preserving the social culture of a local community.

This statement by a local community figure can be interpreted in different ways. According to the opinion of the writer, after carrying out an analysis and direct interviews with a number of members of the community, there are several things that can be problematic when a person decides to enter into the world of business (home industry) in rural areas, especially in mountainside communities (in this case agricultural based home industries): (1) when a person enters the business world, he or she will feel isolated from their environment, (2) when a person does business, much of their time is taken up with business activities so they are unable to take part in social activities that show a sense of solidarity and togetherness in their life in the community. These conditions may lead to clashes between the social culture and economic culture, which in turn may cause home industries to fail to thrive in rural areas. This is evidence that cultural patterns in rural communities are included in traditional cultural patterns. Traditional cultural patterns are a product of the true influence of nature on communities whose lives depend on nature. Kinship systems also influence the cultural patterns of an area.

This cultural transformation produces a multiplier effect and acts as a trigger and determining factor in rural development. Cultural clashes in the development of home industries, specifically in the banana center in this study, which incidentally is located at the foot of a mountain region, cannot be avoided. The effect of industrialization on social capital occurs in three areas [33], namely migration, an increase in income and enlarged economic gap, and setbacks due to industrialization itself (theories of reverse causality). Table 3 shows the clashes between the agrarian culture and industrial culture that have occurred alongside the development of the banana center home industry in Jenawi.

In line with the cultural transformation taking place in the development of home industries, the government has a crucial role to play in developing home industries that empower communities so that there is no marginalization of members of the community in their access to networks of capital, markets, and partnerships. In addition, it is vital that the government makes regulations to protect creative economy businesses at a local level so that they are not pushed aside by the influx of capitalism in rural areas. This is in line with the statement of [35], that one example of conservative economic development is to start up a local industry. There is greater potential for using local resources, initiative, and workers to build new local industries that are owned by and run by people in the local community. People in local communities who have ideas for new businesses can change their dreams into reality. Therefore, the presence of local government is extremely important for creating special regulations related to accessibility to capital, while institutions of higher education are responsible for transferring knowledge of technology and management on a small rural scale. 
Table 3. Cultural Clashes in the Development of Home Industries

\begin{tabular}{|c|c|c|c|}
\hline No & $\begin{array}{l}\text { Dimension } \\
\text { of Interests }\end{array}$ & $\begin{array}{c}\text { Indicator of Clash between } \\
\text { Industrial Culture and } \\
\text { Agrarian Culture } \\
\end{array}$ & Condition in the Community \\
\hline \multirow{3}{*}{1} & \multirow{3}{*}{$\begin{array}{l}\text { Production } \\
\text { Input }\end{array}$} & \multirow{2}{*}{$\begin{array}{l}\text { Agrarian culture positions } \\
\text { people/workers more as a } \\
\text { resource to support the production } \\
\text { process, while industrial culture } \\
\text { positions people/workers as a } \\
\text { factor of production. }\end{array}$} & $\begin{array}{l}\text { Decline in the ability to work together } \\
\text { voluntarily. }\end{array}$ \\
\hline & & & $\begin{array}{l}\text { People start to feel that in order to obtain } \\
\text { anything as production input, even the } \\
\text { smallest amount, they must spend money, } \\
\text { which is different from what they can get } \\
\text { from their neighbours. }\end{array}$ \\
\hline & & $\begin{array}{l}\text { A pattern of income sharing to } \\
\text { establish kinship relationships is } \\
\text { the main focus of agrarian culture } \\
\text { while a wage system based on } \\
\text { skill or expertise is implemented } \\
\text { in industrial culture. }\end{array}$ & $\begin{array}{l}\text { Increase in diversification of job types } \\
\text { that offer a wage. Previously, when } \\
\text { building a house, wages would only be } \\
\text { given to skilled labourers, usually from } \\
\text { outside the village, but nowadays } \\
\text { everyone who works to help building a } \\
\text { house is paid. }\end{array}$ \\
\hline \multirow[t]{2}{*}{2} & \multirow[t]{2}{*}{$\begin{array}{l}\text { Production } \\
\text { Process }\end{array}$} & $\begin{array}{l}\text { Agrarian culture views people as } \\
\text { having potential that should be } \\
\text { developed to manage natural and } \\
\text { environmental resources while } \\
\text { industrial culture views people as } \\
\text { machines for producing products }\end{array}$ & $\begin{array}{l}\text { In the past, people did not work according } \\
\text { to standard work hours (more flexible) but } \\
\text { today any work that receives a wage is } \\
\text { done based on standard work hours. }\end{array}$ \\
\hline & & $\begin{array}{l}\text { In agrarian culture there is high } \\
\text { tolerance and flexibility for work } \\
\text { hours and break times while in } \\
\text { industrial culture there are clear } \\
\text { limits to work hours and breaks. }\end{array}$ & $\begin{array}{l}\text { In the past, times for starting work, taking } \\
\text { a break, and stopping work were very } \\
\text { flexible, depending on conditions, but } \\
\text { nowadays everything is scheduled like } \\
\text { work in industries, and any extra time } \\
\text { worked is counted as overtime, for which } \\
\text { there is additional pay. }\end{array}$ \\
\hline 3 & $\begin{array}{l}\text { Product } \\
\text { Marketing }\end{array}$ & $\begin{array}{l}\text { Agrarian culture still adheres } \\
\text { closely to principles of fairness in } \\
\text { product marketing while } \\
\text { industrial culture develops and is } \\
\text { dominated by a market economy } \\
\text { relationship. Where there is } \\
\text { money, there are goods. }\end{array}$ & $\begin{array}{l}\text { There is an indication that in marketing } \\
\text { agrarian products, prices are relatively } \\
\text { stable, but in current conditions there are } \\
\text { sharp fluctuations of prices. }\end{array}$ \\
\hline 4 & Impact & $\begin{array}{l}\text { Agrarian culture places more } \\
\text { importance on business } \\
\text { sustainability in the future and is } \\
\text { oriented towards the benefit of the } \\
\text { people, while industrial culture } \\
\text { tends to maximize profit at the } \\
\text { present time. }\end{array}$ & $\begin{array}{l}\text { In the past, farming enterprises were } \\
\text { carried out to meet life necessities and any } \\
\text { surplus was for the common interests of } \\
\text { the people, without much expectation of } \\
\text { profit, but nowadays all activities in } \\
\text { farming enterprises are calculated in terms } \\
\text { of their profit. }\end{array}$ \\
\hline
\end{tabular}

\section{Conclusions}

The development of home industries in rural areas is full of dynamics in the cultural transformation from an agrarian culture to an industrial culture. This cultural transformation produces a multiplier effect and is the trigger and determining factor in rural development. Based on the description of the development of rural economy, it is clear that the government has a very important role to play in facilitating access to capital, markets, and partnerships. In addition, it is important that the government makes regulations to protect 
agricultural based home industries at a local level so that they are not pushed aside by the influx of capitalism in rural areas.

\section{References}

1. Ardianty, M. E., Murdianto. 2018. Dampak Industrialisasi Pedesaan Terhadap Kesejahteraan Rumah Tangga. Jurnal Sains Komunikasi dan Pengembangan Masyarakat Vol 2(5):627-638.

2. Hidayat, R., Andarini, S. 2020. Strategi Pemberdayaan UMKM di Pedesaan Berbasis Kearifan Lokal di Era Industri 4.0 Menuju Era Society 5.0. Jurnal Bisnis Indonesia Vol 1(1):93-109.

3. Hermawati. 2018. Perubahan Pola Kehidupan di Era Industri. Jurnal Bimbingan dan Konseling Islam Vol 1(1):26-38.

4. Nurwahid, M. F., Susanto, H., Ekwandari, Y. S. 2019. Perkembangan Industri Tahu Masyarakat Pekon Gadingrejo Kecamatan Gadingrejo Kabupaten Pringsewu Tahun 1965-1990. Jurnal Pendidikan dan Penelitian Sejarah Vol 7(1):1-12.

5. Effendi, H., Osmet, Ifdal. 2019. Peranan Industri Songket Dalam Meningkatkan Pendapatan Rumah Tangga Pengrajin di Nagari Halaban Kabupaten Lima Puluh Kota. Jurnal Ilmu Sosial dan Ilmu Politik Vol 9(2):159-167.

6. Lekhanya, L. M. 2018. The Use Modern Technology for Rural Industrialization and Its Implications on the Rural SMEs Economic Growth. Journal of Economics and Behavioral Studies Vol 10(6):64-71.

7. Sharma, P. 2018. Rural Industrialization: Role of Government Agencies. International Research Journal of Engineering and Technology Vol 5(6):1-4.

8. Sumardi, L., \& Hanum, F. (2019). Social mobility and new form of social stratification: Study in Sasak tribe, Indonesia. International Journal of Scientific \& Technology Research, 8(10), 708-712.

9. Kiani, A., et al. 2020. Prioritizing the Criteria of Establishment and Development of Aagricultural Industries in the Rural Areas (Case Study: Tehran Province). Sarhad Journal of Agriculture Vol 36(2):668-674.

10. Rizkianto, N., \& Topowijono, T. (2018). Penerapan konsep community based tourism dalam pengelolaan daya tarik wisata berkelanjutan (Studi pada Desa Wisata Bangun, Kecamatan Munjungan, Kabupaten Trenggalek). Jurnal Administrasi Bisnis, 58(1), 20-26.

11. Petrovic, M. D., et al. 2018. Tourism as an Approach to Sustainable Rural Development in Post-Socialist Countries: A Comparative Study of Serbia and Slovenia. Journal Sustainability Vol 10(1):54-68.

12. Rhama, B. 2019. Peluang Ekowisata Dalam Industri 4.0 di Indonesia. Jurnal Ilmu Sosial, Politik dan Pemerintahan Vol 8(2):37-49.

13. Siddiq, I. H. A., Saputra, M., Untari, S. 2018. Rural Industrialization and The Impact on Citizens. Journal ASSEHR Vol 313(1):285-289.

14. Zhu, J., et al. 2019. Urbanization for Rural Development: Spatial Paradigm Shifts Toward Inclusive Urban-Rural Integrated Development in China. Journal of Rural Studies Vol 71(1):94-103.

15. Wati, E. R., Irham, M. A. 2020. Industrialisasi dan Perubahan Sosial Ekonomi Masyarakat Muslim di Desa Kecubung Terbanggi Besar Lampung Tengah. Jurnal Sosiologi Agama Vol 1(1):1-18. 
16. Riwanto, Astuti, N. W.W. 2020. Industrialisasi dan Perubahan Gaya Hidup. Jurnal Social Studies Vol 8(1):1-9.

17. Chaerudin, A. R., Setiadi, B. Munawir, A. 2020. Pemberdayaan Ekonomi Masyarakat Berbasis Ekonomi Kreatif di Desa Citaman Kecamatan Ciomas Kabupaten Serang Banten. Jurnal Abdimas Bina Bangsa Vol 1(1):26-37.

18. Wang, F., Prominski, M. 2020. Landscapes with locality in urban or rural areas. Indoor and Built Environment. Vol 29(8): 1047-1052

19. Vaishar, A. et al. 2018. Quality of Rural Life Editorial. J Europ Countrys. 10(2): 180190.

20. Mulyana, D. (2008). Metodologi penelitian kualitatif, paradigma baru Ilmu Komunikasi dan ilmu sosial lainnya. Bandung: Remaja Rosdakarya.

21. Forman, J., Creswell, J. W., Damschroder, L., Kowalski, C. P., \& Krein, S. L. (2008). Qualitative research methods: key features and insights gained from use in infection prevention research. American journal of infection control, 36(10), 764-771.

22. Hancock, D. R., \& Algozzine, B. (2017). Doing case study research: A practical guide for beginning researchers. Teachers College Press.

23. Mihalache, G. (2019). Heuristic inquiry: Differentiated from descriptive phenomenology and aligned with transpersonal research methods. The Humanistic Psychologist, 47(2), 136.

24. Rosalyn, M. E., \& Kuncoroyakti, Y. A. (2019). Komunikasi Antar Budaya Pada Komunitas Perca (Studi Fenomenologi). Jurnal Riset Komunikasi, 2(1), 29-37.

25. Harrison, H., Birks, M., Franklin, R., \& Mills, J. (2017, January). Case study research: Foundations and methodological orientations. In Forum Qualitative Sozialforschung/Forum: Qualitative Social Research (Vol. 18, No. 1).

26. Rudolph, J. Leedy, PD, \& Ormrod, JE (2015). Practical research. Planning and design. Boston, MA: Pearson. Journal of Applied Learning and Teaching, 1(2), 73-74.

27. Yin, R. K. (2011). Applications of Case Study Research. Sage Publications.

28. Gliner, J. A., Morgan, G. A., \& Leech, N. L. (2016). Research methods in applied settings: An integrated approach to design and analysis. Routledge.

29. Corbin, J. (2021). Strauss's Grounded Theory. In Developing Grounded Theory (pp. 25-44). Routledge.

30. Bogdan, R. C. dan Biklen, SK 1982. Qualitative Research for Education: An Introduction to Theory and Methods

31. Miles, M. B., Huberman, A. M., \& Saldaña, J. (2018). Qualitative data analysis: A methods sourcebook. Sage publications.

32. Laah, E. D., Adefila, J., \& Yusof, R.(2019). Community participation in sustainable rural infrastructuraldevelopment in Riyom Area, Plateau State of Nigeria.Journals of Economics and Sustainable Development, 5 (4):49-57.

33. Oino, Peter Gutwa, Geofrey Towett, K. K. Kirui, and Cyrillah Luvega. "The dilemma in sustainability of community-based projects in Kenya." (2015).

34. Nedumaran G, Manida M. 2020. E-Agriculture And Rural Development In India. Journal of Composition Theory XIII(I): 105-114.

35. Ife, J., \& Tesoriero, F. (2008). Community development: Alternative community development in the era of globalization. Translated by Sastrawan Manullang, Nurul Yakin dan M. Nursyahid. Yogyakarta [ID]. Pustaka Pelajar. 